\title{
A supratentorial primitive neuroectodermal tumor presenting with intracranial hemorrhage in a 42-year-old man: a case report and review of the literature
}

\author{
Evangelos K Papadopoulos, Kostas N Fountas, Alexandros G Brotis and Konstantinos N Paterakis*
}

\begin{abstract}
Introduction: We report on a very rare case of a supratentorial primitive neuroectodermal tumor in an adult, which presented with intracerebral hemorrhage, and review the relevant medical literature.

Case presentation: A 42-year-old Caucasian man complained of a sudden headache and nausea-vomiting. The patient rapidly deteriorated to coma. An emergency computed tomography scan showed an extensive intraparenchymal hemorrhage that caused significant mass effect and tonsilar herniation. During surgery, an increased intracranial pressure was recorded and extensive bilateral decompressive craniectomies were performed. A cherry-like intraparenchymal lesion was found in his right frontal lobe and resected. The patient died in the intensive care unit after approximately 48 hours. The resected lesion was identified as a central nervous system primitive neuroectodermal tumor.

Conclusion: Supratentorial primitive neuroectodermal tumors must be considered in the differential diagnosis of space-occupying lesions in adults. Spontaneous supratentorial hemorrhage due to primitive neuroectodermal tumors is an extremely rare but potentially lethal event.
\end{abstract}

\section{Introduction}

Primitive neuroectodermal tumors (PNET) constitute a heterogeneous group of embryonal malignancies that are composed of undifferentiated or poorly differentiated cells and are characterized by an aggressive clinical behavior $[1,2]$. They usually occur in children and adolescents and may arise in the cerebral hemispheres, the brainstem or the spinal cord [1,3]. Although they are common primary central nervous system tumors in children, PNETs are extremely rare in adults, representing less than $0.5 \%$ of all intracranial tumors [4]. The definition of PNETs in the 2007 World Health Organization (WHO) classification of tumors affecting the central nervous system is made regardless of their supra- or infratentorial location [2].

\footnotetext{
*Correspondence: kpaterakis@yahoo.com

Department of Neurosurgery, University Hospital of Larissa, School of Medicine, University of Thessaly, Building A, 3rd Floor, Biopolis, Larisa 41110, Greece
}

PNETs in adults usually present with signs of increased intracranial pressure (ICP), seizures and/or focal neurological deficits [4-15]. However, to the best of our knowledge, there is no report on a supratentorial PNET presenting with a massive and fatal intracerebral hemorrhage. In this case report, we present the case of a patient with a supratentorial PNET, presenting with massive intracerebral hemorrhage. With this opportunity, we also review the pertinent literature.

\section{Case presentation}

A 42-year-old Caucasian man was admitted to the emergency department of a district hospital in a comatose condition (Glasgow Coma Scale Score 4 out of 15). His relatives reported that he initially complained of a sudden onset of headache and had several episodes of emesis. He was sedated, intubated and urgently transported to our teaching hospital. On arrival at our facility, he was unresponsive to verbal and painful stimuli, and his pupils were bilaterally dilated and non- 


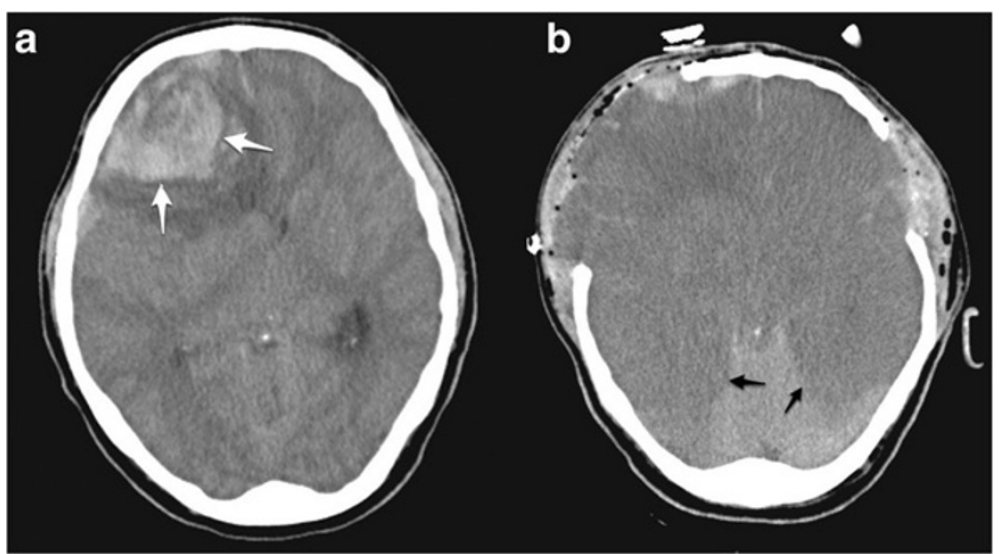

Figure 1 Computed tomography scan images. (a) Preoperative brain computed tomography scan showing an extensive intraparenchymal hemorrhagic lesion in the right frontal lobe (white arrows), with severe diffuse perilesional edema affecting the whole ipsilateral hemisphere, and compressing the ipsilateral lateral ventricle and causing significant mass effect. (b) Immediate postoperative computed tomography scan showing the low-density appearance of both the cerebral hemispheres, suggesting severe brain ischemia (black arrows).

reactive. An urgent computed tomography $(\mathrm{CT})$ scan of his brain showed an extensive intraparenchymal hemorrhagic lesion, causing significant mass effect and tonsilar herniation (Figure 1a).

An external ventricular drain was inserted into his left lateral ventricle, and an intraparenchymal ICP fiber optic monitor was inserted into the right frontal perilesional area. His ICP was elevated $(>40 \mathrm{mmHg})$, and extensive bilateral decompressive craniectomies were urgently performed. During the surgery, and after the evacuation of the hematoma, a cherry-like intraparenchymal lesion was found in his edematous right frontal lobe, which

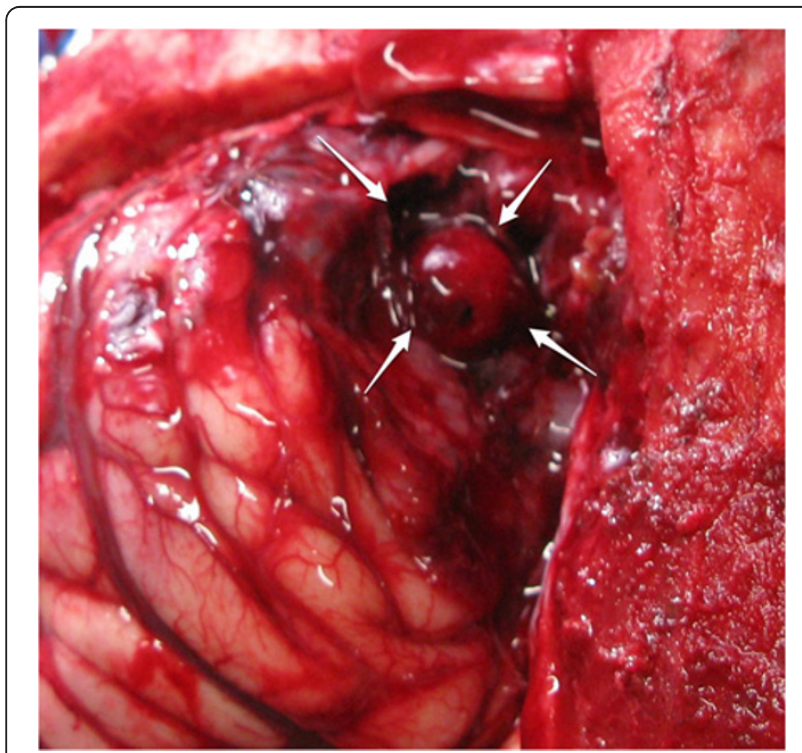

Figure 2 Intraoperative photograph. A cherry-like round lobulated lesion was demonstrated in the right frontal lobe (white arrows). was resected (Figure 2). Decompressive duraplasties were performed bilaterally and after surgery he was transferred to the intensive care unit for observation and further management.

A head CT scan at the end of surgery showed diffuse areas of low-density in both brain hemispheres, suggesting severe ischemia (Figure 1b). His condition continued to deteriorate, with ICP rising to $65 \mathrm{mmHg}$ despite the performed decompressive craniectomies and the aggressive medical management of his intracranial hypertension. He subsequently developed multi-organ failure, and died approximately 48 hours after his admission.

The surgical specimen was sent for microscopic and immunohistochemical pathological analysis. Permanent specimen sections were stained with hematoxylin and eosin and were assessed via immunohistochemistry for vimentin, synaptophysin, glial-fibrillary acidic protein and Ki-67 to measure the proliferation index. Uniform neoplastic medium-sized cells, with round to oval hyperchromatic nuclei, were present and positive for vimentin, synaptophysin and cluster of differentiation 56 , but were negative for glial-fibrillary acidic protein (Figure 3). The Ki-67 index was approximately $40 \%$, indicating increased mitotic activity and a high-grade malignancy. The resected lesion was identified as a central nervous system PNET.

\section{Discussion}

The term PNET was introduced in 1973 for describing initially supratentorial, pediatric brain tumors that were largely undifferentiated or primitive but contained small foci of glial or neuroblastic differentiated cells of primitive neuroectodermal origin [1]. PNETs of the central nervous system include neuroblastomas, ganglioneuroblastomas, 


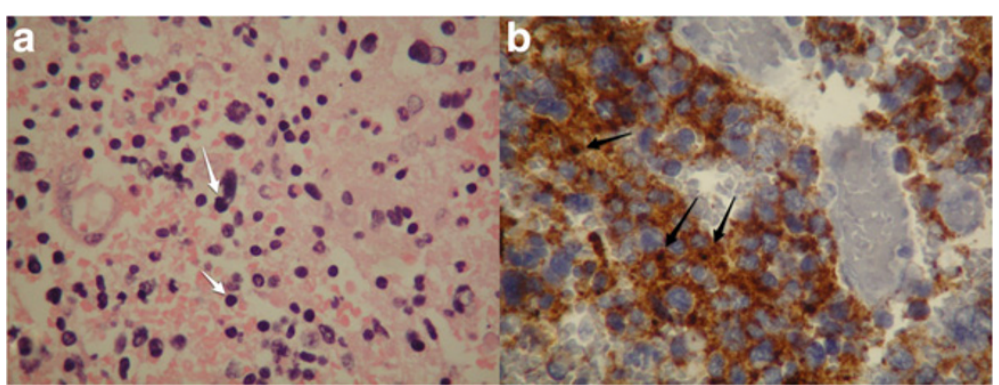

Figure 3 The histological findings were compatible with primitive neuroectodermal tumor. (a) Photomicrograph (original magnification, $\times 100$; hematoxylin-eosin stain) demonstrating small tumor cells with round to oval hyperchromatic nuclei and scant cytoplasm with distinct outline (white arrows). (b) Photomicrograph (original magnification, $\times 400$; immunohistochemical stain) showing intense positivity for synaptophysin (black arrows).

medulloepitheliomas, ependymoblastomas, embryonal tumors with abundant neuropil and true rosettes, and not otherwise specified PNET tumors [2]. The previous longstanding controversy regarding the inclusion of medulloblastomas and pineoblastomas into the PNET category has been resolved by the WHO tumor classification [2].

We performed a literature review in MEDLINE and PubMed, limited to the English language and ranging from January 1973 to December 2012. We used as key terms the words 'PNET' or 'primitive neuroectodermal tumour', intracerebral hemorrhage' or 'intracerebral haemorrhage' or 'intracerebral bleeding' and 'adults', 'man', 'woman'. No patients younger than 20 years old were included in the literature review. Altogether, 278 articles were retrieved. Two of the authors (EKP and AGB) read the abstracts of the gathered articles and all irrelevant articles were eliminated. The full-text articles of the remaining hits were gathered and thoroughly studied and their references scrutinized for further relevant cases. The results are presented in Table 1.

Twenty six publications have reported on 70 supratentorial not otherwise specified PNET cases in adults. These tumors occurred in adults up to 88 years old [11] with a small overall male predominance (male to female ratio, four to three) (Table 1).

Most patients present with symptoms and signs of raised ICP such as headaches, nausea and/or vomiting, confusion and papilledema because of the rapid tumor growth $[4,6-8,13,15]$, as in our case. Furthermore, an adult supratentorial PNET may present with focal neurological signs and deficits, such as limb paresis, aphasia, facial palsy and visual field defects, depending on the anatomic location of the tumor $[7,10,11,14,18,22,23,26]$. Occasionally, the clinical presentation may involve seizures $[5,9,12]$. To the best of our knowledge, this is the first report of a patient with a supratentorial PNET presenting in a comatose condition due to massive intracranial hemorrhage.

Adult PNETs demonstrate no specific imaging characteristics in comparison to their counterparts in children.
They may appear as isodense or hyperdense lesions on a CT scan, with intratumoral calcifications or microhemorrhages [4]. On magnetic resonance imaging, they usually appear as multilobulated, well-demarcated masses, showing heterogeneous signal intensity on T1 and T2 weighted images. They may have cystic, necrotic or hemorrhagic components, while their solid parts usually appear hypointense on T1-weighted and hyperintense on T2-weighted images, and they enhance after intravenous administration of a paramagnetic contrast. Moderate to severe surrounding edema is usually present in adult supratentorial PNETs [4]. Proton magnetic resonance spectroscopic studies have shown nonspecific increased choline and lactate, and decreased $\mathrm{N}$-acetyl-aspartate concentrations. The differential preoperative diagnosis of suspected supratentorial PNET should include glioblastoma, anaplastic oligodendroglioma and metastatic tumor. It has to be emphasized that the possibility of mislabeling a diffuse highly malignant glioma with foci resembling PNET is extremely high [3].

On macroscopic examination, adult PNETs usually appear as lobulated, purple-grayish or pinkish masses. On histology, the tumor cell population consists of undifferentiated small cells with ill-defined, scanty cytoplasm, and round or oval cells with hyperchromatic nuclei $[2,3]$. Mitotic activity is variable. Microscopic calcifications, necroses and Homer-Wright rosettes are also observed in a number of cases. The vascularity of the tumors varies, whereas endothelial cell proliferation within the vessel wall is regularly observed $[2,3,15]$.

Newer genetic analysis studies have demonstrated that PNETs are characterized by MYCN or MYCC gene amplifications, and polysomies of chromosomes 2 and 8 [3]. Various genetic features seem to be associated with prognosis and clinical outcome. The presence of $M Y C N$ or MYCC gene amplifications has been shown to be associated with decreased survival. Similarly, polysomies of chromosomes 2 and 8 have been individually associated with decreased survival in children, and the combined presence appears to be an even more unfavorable 
Table 1 Summary table of case reports on adult patients with supratentorial primitive neuroectodermal tumor

\begin{tabular}{|c|c|c|c|c|c|c|c|}
\hline Study & $\begin{array}{l}\text { Number of } \\
\text { patients }\end{array}$ & Age (years) & Sex & Clinical presentation & $\begin{array}{l}\text { Intracerebral } \\
\text { hemorrhage }\end{array}$ & Treatment & Outcome \\
\hline Bellis et al. [5] & 1 & 57 & M & Seizures & No & $S, R$ & Died after five months \\
\hline Gaffney et al. [6] & 7 & 22 to 35 & $2 \mathrm{~F}+5 \mathrm{M}$ & Increased ICP & No & $S, \pm R, \pm C$ & $\begin{array}{l}\text { Seven months to } \\
\text { nine years }\end{array}$ \\
\hline Kuratsu et al. [7] & 1 & 31 & M & $\begin{array}{l}\text { Headache, hemiparesis, } \\
\text { papilledema }\end{array}$ & No & $S, C$ & Died after 15 months \\
\hline Louis et al. [16] & 1 & 40 & M & Hydrocephalus & No & $S, R$ & $\begin{array}{l}\text { Spinal metastasis after } \\
18 \text { years }\end{array}$ \\
\hline Miyazawa et al. [17] & 1 & 21 & $\mathrm{~F}$ & Headache & No & $S, R, C$ & 27 years follow-up \\
\hline Selassie et al. [18] & 1 & 60 & M & Visual difficulty & No & $S, R, C$ & Died after eight months \\
\hline Pickuth and Leutloff [8] & 5 & 20 to 57 & $2 \mathrm{~F}+3 \mathrm{M}$ & Increased ICP & No & $S, \pm R, \pm C$ & $\begin{array}{l}\text { Died after four to } \\
25 \text { months }\end{array}$ \\
\hline Sanno et al. [9] & 1 & 50 & $\mathrm{~F}$ & Seizures & No & $S$ & NS \\
\hline Takeuchi et al. [19] & 1 & 69 & M & $\begin{array}{l}\text { Decline of higher } \\
\text { cortical functions }\end{array}$ & No & $S, R, C$ & 30 months follow-up \\
\hline Gyure et al. [20] & 4 & 30 to 40 & $4 \mathrm{M}$ & Various & No & $S, \pm R, \pm C$ & $\begin{array}{l}\text { Died after two to } \\
\text { five years }\end{array}$ \\
\hline Prados et al. [21] & 4 & 21 to 42 & $3 M+1 F$ & Not specified & No & $S, R, C$ & 23 to 66 months \\
\hline Gnanaligham et al. [22] & 1 & 38 & $\mathrm{~F}$ & Vertigo - diplopia & No & S & Died after five months \\
\hline Krishnamurthy et al. [23] & 1 & 51 & $\mathrm{~F}$ & Visual field defects & No & $S, R, C$ & $\begin{array}{l}\text { Alive at } 18 \text { months } \\
\text { follow-up }\end{array}$ \\
\hline Balafouta et al. [10] & 1 & 60 & M & $\begin{array}{l}\text { Headache, Broca's aphasia } \\
\text { and hemiparesis }\end{array}$ & No & $S, R, C$ & 12 months \\
\hline Majós et al. [24] & 7 & 21 to 67 & NS & NS & No & NS & NS \\
\hline Kim et al. [4] & 12 & 20 to 64 & $6 \mathrm{M}+6 \mathrm{~F}$ & Increased ICP & No & $S, \pm R, \pm C$ & $\begin{array}{l}\text { Mean survival } 86 \\
\text { months }\end{array}$ \\
\hline Kouyialis et al. [25] & 1 & 32 & $\mathrm{~F}$ & $\begin{array}{l}\text { Headaches, fatigue, } \\
\text { gait disturbances }\end{array}$ & No & S & Alive at 24 months \\
\hline Shingu et al. [11] & 1 & 88 & $\mathrm{~F}$ & $\begin{array}{l}\text { Disturbance of consciousness, } \\
\text { left hemiplegia }\end{array}$ & No & Biopsy, C & Died after six months \\
\hline Krampulz et al. [12] & 1 & 33 & M & Seizures, dizziness & No & $S, R, C$ & Alive after 17 years \\
\hline Han et al. [13] & 1 & 29 & M & Increased ICP & No & $S, R, C$ & $\begin{array}{l}\text { Died after two years } \\
\text { from spine and lung } \\
\text { metastases }\end{array}$ \\
\hline \multirow[t]{2}{*}{ Terheggen et al. [26] } & 1 & 26 & M & $\begin{array}{l}\text { Headache, nausea, } \\
\text { coordination problems and } \\
\text { monoparesis }\end{array}$ & No & $S, R$ & $\begin{array}{l}\text { Multiple liver metastases } \\
\text { and local tumor } \\
\text { recurrence }\end{array}$ \\
\hline & & & & & & & Alive after four years \\
\hline Ohba et al. [14] & 1 & 56 & M & Facial palsy & No & $S, R$ & Died after five months \\
\hline \multirow[t]{2}{*}{ Prayson [27] } & 1 & 48 & $\mathrm{~F}$ & Headaches and confusion & No & $S$ & $\begin{array}{l}\text { Recurrence after } 10 \\
\text { months }\end{array}$ \\
\hline & & & & & & & Died after 13 months \\
\hline Gessi et al. [28] & 12 & 32 to 64 & $6 \mathrm{~F}+6 \mathrm{M}$ & NS & No & NS & $\begin{array}{l}\text { Varied from death at } \\
\text { two months to five } \\
\text { years disease free }\end{array}$ \\
\hline Lawandy et al. [15] & 1 & 22 & M & Increased ICP & No & S & NS \\
\hline Present case & 1 & 42 & M & Coma & $\begin{array}{l}\text { Massive } \\
\text { intracerebral } \\
\text { hemorrhage }\end{array}$ & S & Death \\
\hline
\end{tabular}


prognostic factor [3]. The vast majority of the genetic characteristics are based on pediatric cases because adult cases are extremely rare. Therefore, extrapolation of the prognostic role of such genetic features in PNET cases in adults may be inaccurate.

Extensive surgical resection of adult PNET is the usually recommended mode of treatment, followed by radiotherapy and chemotherapy (Table 1). Postsurgical irradiation of the whole craniospinal axis may be employed, even when there is no evidence of spinal seeding [4]. The employed mean dose is 54Gy for the brain and 31Gy for the spinal cord [4]. The exact role of stereotactic radiosurgery employment, especially in cases of partially resected PNET tumors, remains to be defined $[2,4]$.

The prognosis for adults with supratentorial PNETs seems to be worse than that of their pediatric counterparts $[3-5,7,29]$. The reported overall survival of PNETs in the pediatric population ranges between $29 \%$ and $57 \%$ [3], whereas Kim et al. [4] reported three-year mean survival of $75 \%$ in their series of adult patients. Most adults, with limited exceptions, with a supratentorial PNET die within a year of the initial diagnosis (Table 1). There are a few reports on local recurrence and spinal and lung metastases $[13,16,26,27]$. For pediatric patients with supratentorial PNETs, the prognosis correlates with age, extent of necrosis and tumor dissemination [4]. By contrast, in adults the most important prognostic factor is considered to be the Ki-67 index. Kim et al. [4] reported that adult patients with a Ki-67 index greater than 30\% demonstrated very poor outcome, with a mean postoperative survival time of eight months. Similarly, in our patient, his labeling index Ki-67 was approximately $40 \%$.

\section{Conclusions}

Supratentorial PNETs must be considered in the differential diagnosis of space-occupying lesions in adults. Spontaneous supratentorial hemorrhage is an extremely rare but potentially lethal presentation of PNET in adults.

\section{Consent}

Written informed consent was obtained from the patient's relatives for publication of this case report and accompanying images. A copy of the written consent is available for review by the Editor-in-Chief of this journal.

\section{Competing interests}

The authors declare that they have no competing interests.

\section{Authors' contributions}

All authors contributed in writing the manuscript. EKP and AGB performed the literature review. KNF was responsible for the text editing. AGB was responsible for writing the manuscript. KNP was in charge of manuscript supervision and is the corresponding author. All authors read and approved the final manuscript.
Received: 9 July 2012 Accepted: 28 January 2013

Published: 27 March 2013

\section{References}

1. Hart MN, Earle KM: Primitive neuroectodermal tumours of the brain in children. Cancer 1973, 32:890-897.

2. Louis DN, Ohgaki H, Wiestler OD, Cavenee WK, Burger PC, Jouvet A, Scheithauer BW, Kleihues P: The WHO classification of tumours of the central nervous system. Acta Neuropathol 2007, 2007(114):97-109.

3. Behdad A, Perry A: Central nervous system primitive neuroectodermal tumors: a clinicopathologic and genetic study of 33 cases. Brain Pathol 2009, 20:441-450.

4. Kim DG, Lee DY, Paek SH, Chi JG, Choe G, Yung HW: Supratentorial primitive neuroectodermal tumors in adults. J Neurooncol 2002, 60:43-52.

5. Bellis EH, Salcman M, Bastian FO: Primitive neuroectodermal tumor in a 57-year-old man. Surg Neurol 1983, 20:30-35.

6. Gaffney CC, Sloane JP, Bradley NJ, Bloom HJ: Primitive neuroectodermal tumours of the cerebrum. Pathology and treatment. J Neurooncol 1985, 3(1):23-33.

7. Kuratsu J, Matsukado Y, Seto H, Nonaka N, Sueyoshi N: Primitive neuroectodermal tumor arising from the thalamus of an adult - case report. Neurol Med Chir (Tokyo) 1986, 26:30-34

8. Pickuth $\mathrm{D}$, Leutloff $\mathrm{U}$ : Computed tomography and magnetic resonance imaging findings in primitive neuroectodermal tumours in adults. Br J Radiol 1996, 69(817):1-5.

9. Sanno N, Shimura T, Takumi I, Tahara S, Node Y, Aihara K, Osamura RY, Teramoto A: An adult case of cerebral primitive neuroectodermal tumour. Acta Neurochir (Wien) 1998, 140(5):445-446.

10. Balafouta MJ, Kouvaris JR, Miliadou AC, Papacharalampous XN, Kolokouris $D V$, Kouloulias VE, Mariolis AD, Vlahos L: Primitive neuroectodermal tumour in a 60-year-old man: a case report and literature review. BrJ Radiol 2003, 76(901):62-65.

11. Shingu T, Kagawa T, Kimura Y, Takada D, Moritake K, Hoshii Y: Supratentorial primitive neuroectodermal tumor in an aged patient case report. Neurol Med Chir (Tokyo) 2005, 45(10):530-535.

12. Krampulz T, Hans VH, Oppel F, Dietrich U, Puchner MJ: Long-term relapsefree survival with supratentorial primitive neuroectodermal tumor in an adult: a case report. J Neurooncol 2006, 77(3):291-294.

13. Han SR, Sohn MJ, Yoon SW, Yee GT, Choi CY, Lee DJ, Whang CJ: Extracranial metastases of a supratentorial primitive neuroectodermal tumour. J Clin Neurosci 2007, 14(1):55-58.

14. Ohba S, Yoshida K, Hirose Y, Ikeda E, Kawase T: A supratentorial primitive neuroectodermal tumor in an adult: a case report and review of the literature. J Neurooncol 2008, 86(2):217-224.

15. Lawandy S, Hariri OR, Miulli DE, Amin J, Minasian T, Gupta RK, Siddiqi J: Supratentorial primitive neuroectodermal tumor in an adult: a case report and review of the literature. J Med Case Rep 2012, 6(1):361.

16. Louis DN, Hochberg FH: Cerebral primitive neuroectodermal tumor in an adult, with spinal cord metastasis after 18-year dormancy. J Neurooncol 1990, 9(1):77-80.

17. Miyazawa T, Ueno H, Hatashita S, Yagishita S: "Undifferentiated" cerebral primitive neuroectodermal tumor in a young adult - case report. Neurol Med Chir (Tokyo) 1994, 34(11):759-762.

18. Selassie L, Rigotti R, Kepes JJ, Towfighi J: Adipose tissue and smooth muscle in a primitive neuroectodermal tumor of cerebrum. Acta Neuropathol 1994, 87(2):217-222

19. Takeuchi H, Kubota T, Sato K, Yao Y, Kitai R, Arishima H: Atypical neuronalglial tumors of cerebral hemispheres in adults with PNET-like component: clinicopathological features of 5 cases. Clin Neuropathol 2003, 22(2):47-56.

20. Gyure KA, Prayson RA, Estes ML: Extracerebellar primitive neuroectodermal tumors: a clinicopathologic study with bcl-2 and CD99 immunohistochemistry. Ann Diagn Pathol 1999, 3(5):276-280.

21. Prados MD, Edwards MS, Chang SM, Russo C, Davis R, Rabbitt J, Page M, Lamborn K, Wara WM: Hyperfractionated craniospinal radiation therapy for primitive neuroectodermal tumors: results of a Phase II study. Int J Radiat Oncol Biol Phys 1999, 43(2):279-285.

22. Gnanalingham KK, Gillespie J, Richardson PL: Magnetic resonance study of multiple primitive neuroectodermal tumours of the cerebrum, cerebellum and spinal cord in an adult. Clin Radiol 2001, 56(7):588-590. 
23. Krishnamurthy S, Powers SK, Towfighi J: Primitive neuroectodermal tumor of cerebrum with adipose tissue. Arch Pathol Lab Med 2001, 125(2):264-266.

24. Majós C, Alonso J, Aguilera C, Serrallonga M, Acebes JJ, Arús C, Gili J: Adult primitive neuroectodermal tumor: proton MR spectroscopic findings with possible application for differential diagnosis. Radiology 2002 225(2):556-566.

25. Kouyialis AT, Boviatsis El, Karampelas IK, Korfias S, Korkolopoulou P, Sakas DE: Primitive supratentorial neuroectodermal tumor in an adult. J Clin Neurosci 2005, 12(4):492-495.

26. Terheggen F, Troost D, Majoie CB, Leenstra S, Richel DJ: Local recurrence and distant metastasis of supratentorial primitive neuro-ectodermal tumor in an adult patient successfully treated with intensive induction chemotherapy and maintenance temozolomide. J Neurooncol 2007, 82(1):113-116

27. Prayson RA: Lipomatous supratentorial primitive neuroectodermal tumor with glioblastomatous differentiation. Ann Diagn Pathol 2009, 13(1):36-40.

28. Gessi M, Setty P, Bisceglia M, Zur Muehlen A, Lauriola L, Waha A, Giangaspero F, Pietsch T: Supratentorial primitive neuroectodermal tumors of the central nervous system in adults: molecular and histopathologic analysis of 12 cases. Am J Surg Pathol 2011, 35(4):573-582.

29. Castel V, Villamón E, Cañete A, Navarro S, Ruiz A, Melero C, Herrero A, Yáñez $Y$, Noguera R: Neuroblastoma in adolescents: genetic and clinical characterization. Clin Transl Oncol 2010, 12:49-54.

doi:10.1186/1752-1947-7-86

Cite this article as: Papadopoulos et al:: A supratentorial primitive neuroectodermal tumor presenting with intracranial hemorrhage in a 42-year-old man: a case report and review of the literature. Journal of Medical Case Reports 2013 7:86.

\section{Submit your next manuscript to BioMed Central and take full advantage of:}

- Convenient online submission

- Thorough peer review

- No space constraints or color figure charges

- Immediate publication on acceptance

- Inclusion in PubMed, CAS, Scopus and Google Scholar

- Research which is freely available for redistribution 